\title{
Lameness in UK Dairy Cows: A review of the current status
}

\author{
Simon Archer BVMS CertCHP MSc MRCVS \\ RCVS Trust Resident in Dairy Herd Health \\ School of Veterinary Medicine and Science \\ University of Nottingham \\ Sutton Bonnington Campus \\ Sutton Bonnington \\ Loughborough \\ LE12 5RD, UK
}

Nick Bell MA VetMB PhD MRCVS

Research Fellow

University of Bristol

Division of Farm Animal Science

Langford

Bristol

BS40 5DU, UK

Jon Huxley BVetMed DCHP Dip.ECBHM PhD MRCVS

RCVS Specialist in Cattle Health and Production

Associate Professor of Farm Animal Production Medicine

School of Veterinary Medicine and Science

University of Nottingham

Sutton Bonnington Campus

Sutton Bonnington

Loughborough

LE12 5RD, UK

$\underline{\text { Introduction }}$

Lameness in dairy cattle has been reported as a concern for welfare and economic reasons for over 20 years. Concerns are being expressed from across the industry about the current state of affairs and a number of initiatives have been launched in response. This article will review the current UK status of lameness in dairy cows, outline our current understanding of the condition and its impacts on welfare and productivity, highlighting areas where evidence is currently lacking. 
Lameness is a term used to describe the clinical presentation of impaired locomotion, regardless of cause. The majority of cases of lameness in dairy cows are associated with a painful hind limb foot lesion. Sole ulcer, white line disease, foul in the foot and digital dermatitis have been demonstrated as the predominant lesion types (Box 1). Claw horn defects associated with sole ulceration and white line disease most often occur in the outer claw of the hind limb. Digital dermatitis lesions are also most commonly identified in hind limbs.

The true extent of the lameness problem in UK dairy herds is unknown but can be estimated from groups of herds that have participated in research studies. Herd level lameness incidence has been recorded ranging from 5 to 170 with typical average values around 50 limb cases per 100 cow-years (Box 2). Based on mobility scoring, lameness prevalence has also been shown to range widely ( 0 to $79 \%$ ) with typically expected values of $25 \%$ to $37 \%$ depending on the farms involved (Box 3 ).

In the absence of an objective method for identifying a case of "lameness", diagnosis remains a subjective assessment reliant on the experience and expertise of the observer; the sensitivity of detection varies considerably between individuals and variability is greatest in milder cases. UK farmers have been shown to under estimate the lameness prevalence in their herds by at least a factor of four (5\% vs 22\% (Whay and others 2002) and $4.8 \%$ vs $25 \%$ (Huxley 2005), in two separate studies). Farmers' prevalence estimates tended to focus on severely lame cows only. Similarly, there was no correlation between farmer estimates of lameness incidence and the incidence calculated from farm records. 
Farmers may only record a case of lameness when medication is administered and these records do not provide an accurate guide to lameness incidence on most farms.

Herd size and production trends in the UK dairy industry (Box 4) would suggest we are placing increasing demands on our cows. Higher yielding cows are at increased risk of all production diseases including lameness and high standards of management are essential to optimise their health and productivity. This is in direct conflict with the absolute or relative reduction in labour on many farms.

For the last four decades mastitis control has received a high profile in the UK dairy industry since milk buyers pay a premium for higher quality milk with a low somatic cell count (an imperfect but reasonable indicator of clinical mastitis on many farms). In contrast, lameness control has received minimal attention. Within a given herd it is high yielding cows that are at greatest risk of lameness, with milk yield falling towards the herd mean during an episode of lameness. Therefore, lost milk production associated with lameness is not tangible at the individual cow level (an indirect cost) and there have been no direct financial incentives from milk buyers for lameness control. As lameness in dairy cows is a painful condition it provides a visible indicator of their welfare; farm assurance schemes and media interest are increasing consumer awareness of the problem. Retailers are now beginning to respond by altering their contractual agreements with suppliers to include aspects of lameness control and monitoring. An extract from such a milk contract is shown in Box 5. 


\section{Mobility scoring}

Mobility scoring refers to a structured subjective system for the assessment of a cows' gait, designed to reduce between observer variations. The background to the terminology has recently been reviewed (Box 6) and the standard scoring system adopted by the industry funded body "DairyCo" (Box 7) provides case definitions for both lame and severely lame cows to aid in early diagnosis. Training in the application of the scoring system is very helpful to improve repeatability within and between observers.

Mobility scoring can be used to assess lameness prevalence on a farm, at a particular point in time (Box 3) and can be used to benchmark groups of similar herds (Box 8). As there are usually more differences than similarities between farms and their management, it is more useful to benchmark herds against themselves by repeatedly scoring the same cows at regular intervals (e.g. monthly or bi-monthly) using the same observer. Herd dynamics can then be used to monitor lameness control plans (Box 9). Dynamic analysis can only be applied if the identity of all cows is recorded whilst they are being scored and they are scored on at least two occasions in a consistent manner. Practical guidelines for consistent mobility scoring are given in Box 10. Regular screening by the veterinary surgeon or an associated paraprofessional has been proposed since 1996 (Clarkson and others 1996) as useful a means of monitoring lameness. 
The effect of lameness on welfare

The very fact that animals alter their gait in response to the discomfort caused indicates that lameness is a painful condition; this has been confirmed by previous work which demonstrated that lame cows were more sensitive to pain (allodynia).

In a number of recent surveys investigating the attitudes of respondents to pain in cattle both farmers and vets subjectively scored lameness as painful. Digital dermatitis was considered a 5 or 6 on a ten point pain scale and similarly white line disease with a subsole abscess was considered a 6 or 7 (Box 11).

Many consider that lameness is currently the most significant welfare issue affecting dairy cattle in the UK because of the level of discomfort caused, the numbers of animals affected and the average duration of clinical episodes $(27 \pm 19$ days in one study).

\section{The effect of lameness on milk yield}

Most studies into the effect of lameness on milk yield have investigated the impacts of "clinical" lameness cases. A clinical case of lameness has been shown to have a significant adverse effect on milk yield (357 kg less per 305 day lactation) both before and after a cow is diagnosed as lame; the effect of different lesion types varies (Box 12). As research has shown the adverse effects of lameness on milk yield can last up to 9 
months, the early diagnosis and treatment of lameness from an economic as well as a welfare perspective is vital.

Recent research by the authors using the DairyCo mobility scoring system has also demonstrated delayed reductions in milk yield associated with lameness (Archer and others 2010). Consistent with previous work based on clinical lameness, cows never identified as lame by serial mobility scoring gave around $1 \mathrm{~kg}$ /day less milk than their lame herd mates; high milk yield is a risk factor for lameness which explains the higher prevalence in mutliparous compared to primiparous cows. It is important to emphasise that any reduction in yield associated with lameness may not be tangible at the herd level because cows that suffer with lameness are higher yielding than the herd average. At the cow level, this study demonstrated that a reduction in milk yield associated with a case of lameness may not occur for several months. The results help validate the use of regular mobility score assessment for diagnosis of lameness at the cow level as well as for herd level monitoring (Box 13).

\section{The effect of lameness on reproduction}

Lameness is a well know contributor to infertility in dairy herds. Evidence from the literature suggests that lameness can impact on all aspects of reproductive efficiency. It has been demonstrated that lame cows suffer from delayed cyclicity; an increased likelihood of receiving treatment for anoestrus and a higher incidence of cystic ovarian disease; once cyclicity is established, lame cows demonstrate a lower frequency of 
standing to be mounted compared to their sound herd mates. Lame cows which are served are less likely to conceive and have an increased risk of conception failure. Unsurprisingly, as a result many papers have demonstrated that lame animals suffer extensions to the calving to first service interval, calving to conception interval, number of days open and calving interval, compared to their healthy herd mates (Huxley 2008).

The economic impact of lameness

As with any disease the costs associated with a lameness case can be split into the direct costs apparent at the time of the event and indirect costs which tend to be "hidden" (Box 14). It has been estimated that an initial lameness case costs around $£ 323.47$ (Willshire and Bell 2009). Such figures should be used with caution as they may not be relevant to current prices or systems of management on a given farm. Box 15 gives the cost of "lost milk" and culls in today's prices.

As lame cows tend to be high yielding and owing to the high cost of replacement farmers may be reluctant for them to be culled for lameness alone, particularly if the are pregnant and there are other priorities of culling. This emphasises the importance of implementing preventative strategies on farms and monitoring the outcome. 


\section{$\underline{\text { Control of lameness }}$}

For the last 40 years the herd level control of contagious mastitis has been based on the "Five Point Plan" developed from high quality intervention studies, which demonstrated the clinical efficacy of each point before proving its effectiveness in practice. In contrast, there are few comparable experimentally proven herd level control measures for bovine lameness. In the absence of controlled intervention studies we currently rely on the "received wisdom" of our senior peers and the results of observational studies which offer correlations between risks and disease but little indication of direct causality in many areas. This has led to the development of some misunderstanding of risk factors, pathogenesis and control measures. Many assumptions have become accepted practice without being validated by high quality science.

It is beyond the remit of the paper to review evidence based approaches to lameness control and in many areas there remain substantial gaps in our knowledge which are in urgent need of filling (e.g. Box 16). The whole area of lameness in cattle is developing rapidly and there have been a number of substantial recent initiatives. Following the multidisciplinary EU "Lamecow" project (which investigated risk factors in husbandry systems, bio-mechanics and morphology of the bovine claw together with knowledge transfer for best practice), the "Healthy Feet Project" supported by the "Tubney Charitable Trust" has developed large quantities of practical advice and information on control (www.cattle-lameness.org.uk). Similarly, the Proceedings of International Ruminant Digit Symposia provides a wealth of relevant papers. In addition two UK 
events, the "Cattle Lameness Conference" (www.cattlelamenessconference.org.uk) and the "National Cattle Mobility Event" (http://www.cattle-lameness.org.uk/National-CattleMobility-Event.php) which aim to disseminate evidence based science and practical advice respectively have been launched over the last few year. The emergence of the National Association of Cattle Foot Trimmers as a credible representative body for foot trimmers should be welcomed by the veterinary profession. The use of fully trained and accredited "Category 1" foot trimmers (http://www.nacft.co.uk/members_list/a-z.htm) should be encouraged and promoted on all farms. DairyCo are committed to addressing lameness in a programme commencing in 2010. Lastly, over the preceding decade there have been some substantial changes to our current understanding of the aetiology and nomenclature of foot lesions, which are summarised in Boxes 1 and 17; the authors would like to draw particular attention to the section on our current understanding of the aetiology of sole ulceration.

\section{$\underline{\text { Conclusion }}$}

The current situation with lameness in UK dairy cows is not dissimilar to that of mastitis 50 years ago. As an area of emerging importance in dairy practice, robust scientific support of control measures and their economic benefit is urgently needed to follow up on the understanding of potential risk factors and pathogenesis provided by the EU lamecow project. Repeated studies have demonstrated that both clinical episodes of lameness and elevated mobility score lead to substantial reductions in milk yield, productivity and fertility and adversely affects the welfare of affected animals. This reduction in milk yield is not seen at the herd level as cows that suffer with lameness are 
the highest yielders; their milk yield reduces towards that for "average cows" that remain sound. Once lame, farmers tend to retain these high yielding animals as replacement costs are high and unlike cows with chronic mastitis, milk quality is not affected and they are often not a risk to other cows (if the lameness is non-infectious). Early and effective treatment following immediate identification of lame cows will deliver cost effective improvements at farm level whilst appropriate evidence based herd level control programs are developed. There are substantial and ongoing opportunities for the profession to provide training to the industry on the appropriate recognition (mobility scoring), monitoring and treatment of lameness in cattle. Training can also ensure that appropriate veterinary intervention is sort in more serious cases and improve the welfare of affected animals.

\section{$\underline{\text { Acknowledgements }}$}

Simon Archer is a Resident in Production Animal Medicine part funded by the RCVS Trust. The authors would also like to thank The Tubney Charitable Trust for their support through the Healthy Feet Project. 


\begin{tabular}{|c|c|c|c|}
\hline & FOUL IN THE FOOT & WHITE LINE DISEASE & DIGITAL DERMATITIS \\
\hline $\begin{array}{l}\text { Disruption of sole horn } \\
\text { production caused by repeated } \\
\text { or continuous injury to } \\
\text { germinal cells within the sole } \\
\text { corium under the } \\
\text { palmaro/plantaro-distal edge } \\
\text { of the distal phalanx resulting } \\
\text { in chronic inflammation and } \\
\text { eventually pathological } \\
\text { exposure of the corium, } \\
\text { classically appearing several } \\
\text { months after calving. Thought } \\
\text { to arise through a combination } \\
\text { of disruption of the } \\
\text { suspensory apparatus in the } \\
\text { claw at or around calving, } \\
\text { descent or movement of the } \\
\text { distal phalanx, combined with } \\
\text { contusion from standing on } \\
\text { concrete and inflammation } \\
\text { within a compartment (the } \\
\text { claw capsule). Contusion is } \\
\text { worsened by claw horn } \\
\text { overgrowth. The region } \\
\text { around the extensor process of } \\
\text { PIII becomes inflamed, } \\
\text { leading to disruption in horn } \\
\text { growth. A reduced digital }\end{array}$ & $\begin{array}{l}\text { An infection in the interdigital } \\
\text { skin and sub cutis with } \\
\text { Fusobacterium necrophorum } \\
\text { (biotypes A and AB) and } \\
\text { potentially other bacteria such as } \\
\text { Prevotella melaninogenica } \\
\text { Prophyromonas asaccharolytica } \\
\text { and Prophyromonas levii . } \\
\text { Often associated with injury to } \\
\text { the interdigital space and } \\
\text { opportunistic infection. Most } \\
\text { commonly affecting cattle in the } \\
\text { first } 2 \text { months of lactation. } \\
\\
\text { Clean and dry cow tracks, free } \\
\text { of stones and other foreign } \\
\text { bodies helps in prevention. } \\
\text { Rushing freshly calved cows } \\
\text { through muddy gateways } \\
\text { containing rubble, in warm } \\
\text { autumn conditions is a } \\
\text { commonly associated with } \\
\text { outbreaks. Interdigital skin } \\
\text { maceration through continual } \\
\text { exposure to wet conditions may } \\
\text { also be a risk. Hence, standing in } \\
\text { contaminated pools of water or }\end{array}$ & $\begin{array}{l}\text { A breakdown of the horn } \\
\text { joining the sole and wall horn. } \\
\text { This can allow tracking of } \\
\text { foreign material into the white } \\
\text { line. The aetiology of white } \\
\text { line disease is poorly } \\
\text { understood. White line horn } \\
\text { quality may be compromised } \\
\text { by calving stress or white line } \\
\text { bruising. Physical forces could } \\
\text { have a role to play, either } \\
\text { indirectly through bruising or } \\
\text { directly through shear forces } \\
\text { associated with flight } \\
\text { movements or uneven walking } \\
\text { surfaces such as grooved } \\
\text { concrete or rough and stoney } \\
\text { tracks. } \\
\text { When cows are out by day and } \\
\text { housed by night there can be a } \\
\text { combination of soft claw horn } \\
\text { from wet climatic conditions, } \\
\text { rain washed tracks introducing } \\
\text { uneven walking surfaces and } \\
\text { loose stones, bruised white } \\
\text { lines from standing on } \\
\text { concrete and shearing forces }\end{array}$ & $\begin{array}{l}\text { Several Treponemes have been } \\
\text { associated with digital dermatitis } \\
\text { lesions (Carter 2009). One of } \\
\text { these, Treponema pedis has been } \\
\text { repeatedly isolated from foot } \\
\text { lesions (the source of infection) } \\
\text { but has yet to be isolated in } \\
\text { slurry. We believe the route of } \\
\text { infection is environmental } \\
\text { although this has not yet been } \\
\text { demonstrated experimentally. } \\
\text { DD should therefore be managed } \\
\text { as any infectious disease, with } \\
\text { special consideration to sources } \\
\text { of infection, routes of spread, } \\
\text { risk factors and susceptible } \\
\text { animals. Early treatment should } \\
\text { minimise the reservoir of } \\
\text { infection, improving the hygiene } \\
\text { of conditions underfoot will } \\
\text { reduce spread as will applying } \\
\text { principles of biosecurity and } \\
\text { biocontainment. The more } \\
\text { vulnerable the animal or group } \\
\text { (e.g. freshly calved heifers are } \\
\text { most vulnerable to acquiring a } \\
\text { severe infection), the more }\end{array}$ \\
\hline
\end{tabular}




\begin{tabular}{l}
\hline cushion is thought to be a \\
compounding factor in heifers \\
and thin cows. Thought not \\
to be directly associated \\
with acidosis or \\
inflammation of the \\
laminae. Hence coriosis \\
rather than laminitis is the \\
more apt term for the \\
disorder leading to sole \\
ulceration. This distinction \\
reduces confusion as \\
laminitis as a condition \\
probably does exist, albeit \\
less commonly, and \\
probably has a dietary \\
aetiology.
\end{tabular}

Managed by improving cow lying comfort and reducing standing times on concrete.

Early detection and treatment is likely to aid recovery but the cow will be vulnerable to recurrence in future. In some cases treatment or rest (given short standing times and good lying comfort) can successfully restore keratinisation before the corium becomes exposed and deep slurry during the housing period should be avoided.

Walking through spent footbaths full of slurry may contribute to infection and spread.

Foul-in-the-foot, once confirmed, is easily treated with a course of an appropriate antibiotic. However, it is important that suspected cases have their feet lifted and the interdigital space examined. Often a foreign body will be discovered as the inciting factor and the necrotic lesion should be cleaned and treated with an appropriate topical antibiotic. Occasionally, opportunistic infection potentially involving several different bacteria can contribute to peracute foul-inthe-foot, also known as 'super foul'. Complications during an outbreak of super foul can result in high rates of involuntary culling.

Management usually involves improvements to underfoot conditions. Regular foot bathing from a changed herding routine. Hence white line disease is often more common at these times, particularly during autumn.

\section{Supplementing diet with} $20 \mathrm{mg}$ biotin per head per day has been shown to reduce clinical incidence. Similarly, increasing the use of nonensiled forages in the diet while increasing dry matter content may achieve a similar response, potentially through increased synthesis of biotin in the rumen or other mechanisms.

Prevention can be achieved by maintaining good cow tracks to reduce risk of foreign body penetration; maintaining even concrete surfaces and minimising standing times on concrete. However, the importance of smooth cow flow, minimized bully cow interactions, not rushing cows and allowing cows plenty of important these become.

Good hygiene is probably most important together with foot bathing using antibiotics, formalin, copper sulphate or organic acids at the appropriate concentrations. Foot bathing can worsen digital dermatitis if performed incorrectly. Use of a pre-wash bath is recommended prior to the cows walking though a medicated bath. The solutions should be changed when grossly contaminated.

Most cases will respond very well to an appropriate topical antibiotic applied to a clean, dry, debrided lesion. The best cure rates are achieved if treatment is continued daily for 3 days at least. 


\begin{tabular}{|c|c|c|}
\hline $\begin{array}{l}\text { infected at the sole surface. } \\
\text { Expert foot trimming on a } \\
\text { routine basis is likely to } \\
\text { restore foot angle and reduce } \\
\text { overloading at the sole ulcer } \\
\text { site, but it is important to } \\
\text { ensure a correct Dutch } 5 \text { step } \\
\text { technique is used, acquired } \\
\text { through expert instruction. } \\
\text { This ensures that the feet are } \\
\text { cut to the correct length (step } \\
\text { 1) level (step 2) and shape } \\
\text { (step 3). The outer claw of the } \\
\text { hind limb or the inner claw of } \\
\text { the front limb is relieved of } \\
\text { weight bearing if a lesion is } \\
\text { present (step 4) and any loose } \\
\text { or under-run horn is removed } \\
\text { (step 5). }\end{array}$ & $\begin{array}{l}\text { of the herd, particularly } \\
\text { transition cows and freshly } \\
\text { calved cows, with a suitable } \\
\text { disinfectant may also be } \\
\text { effective at preventing new } \\
\text { cases. }\end{array}$ & $\begin{array}{l}\text { reducing flight movements. } \\
\text { If caught early, individuals } \\
\text { respond well to treatment. } \\
\text { Uncomplicated white line } \\
\text { separation can be successfully } \\
\text { treated using Dutch } 5 \text { step foot } \\
\text { trimming, removing the loose } \\
\text { wall horn in step 5. Topical } \\
\text { antibiotic should be applied to } \\
\text { any exposed corium. White } \\
\text { line abscesses require draining, } \\
\text { with sufficient horn removed } \\
\text { to ensure the drainage hole } \\
\text { remains patent following } \\
\text { treatment. Severe infections of } \\
\text { the corium (wall ulcer) may } \\
\text { require more intensive and } \\
\text { repeated treatment with } \\
\text { antibiotics and blocks over } \\
\text { many months. }\end{array}$ \\
\hline
\end{tabular}




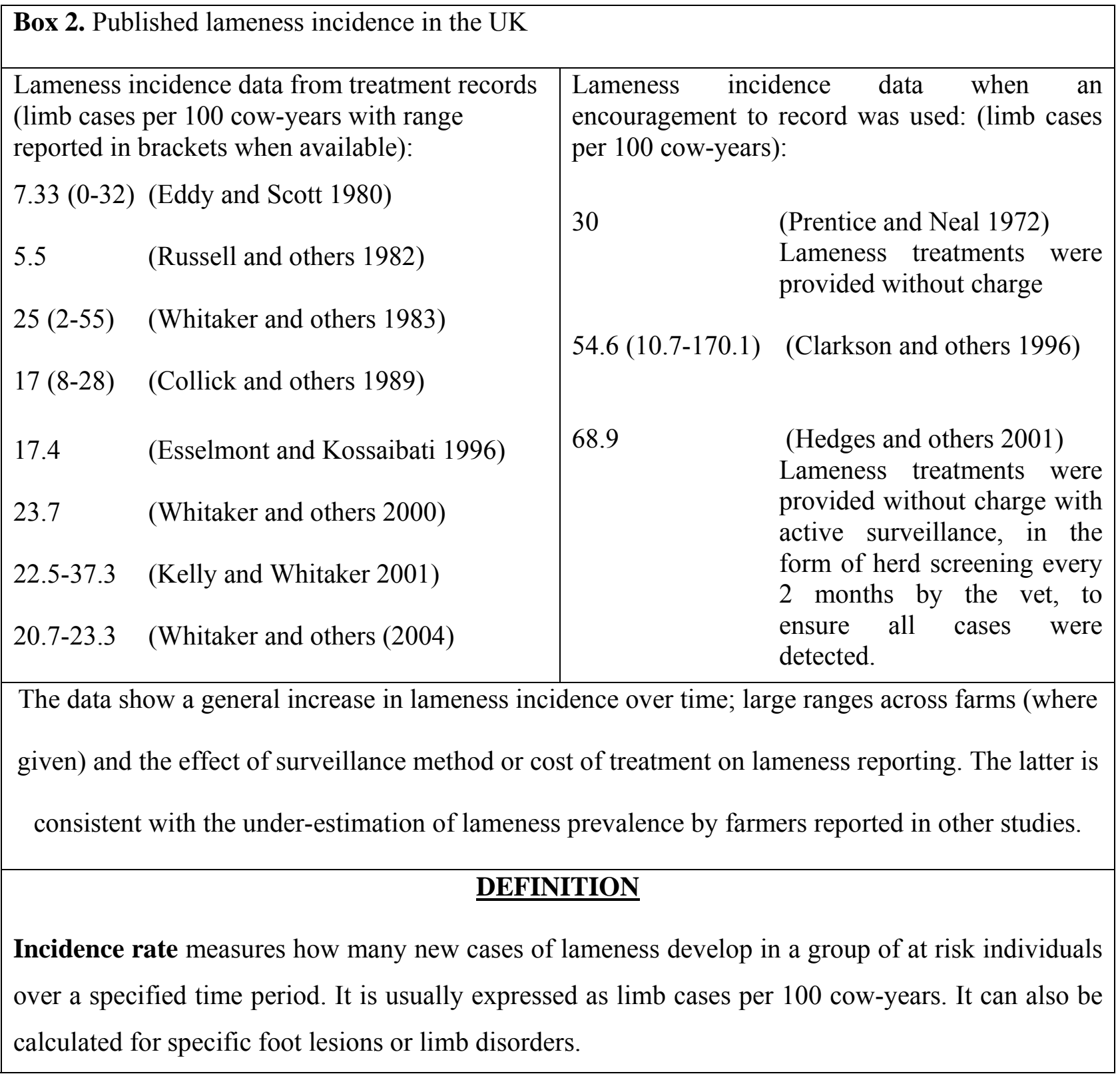




\section{Number of new cases} Time in herd spent not lame

$X 100=$ Limb cases per 100 cow-years

${ }^{\#}$ Where information on the duration of cases is unavailable, the denominator is often approximated by the average number of cows in the herd over the time period considered, i.e. cows present at the start and end of the assessment period. This may lead to an underestimation of the true incidence where lameness detection is poor or cases persist. 
Box 3. Published estimates of lameness prevalence based on mobility scoring

\section{Mean and (range) lameness prevalence:}

\begin{tabular}{|c|c|c|}
\hline $20.6 \%(2.0-53.9)$ & $\begin{array}{l}\text { (Clarkson and } \\
\text { others 1996) }\end{array}$ & $\begin{array}{c}37 \text { herds from the Wirral, } \\
\text { Cheshire, Wales and } \\
\text { Somerset. }\end{array}$ \\
\hline $22.1 \%(0-50.0)$ & $\begin{array}{l}\text { (Whay and others } \\
\text { 2003) }\end{array}$ & $\begin{array}{l}53 \text { herds from the midlands } \\
\text { and South West. } 28 \text { were } \\
\text { recruited from the RSPCA } \\
\text { Freedom Foods scheme. }\end{array}$ \\
\hline $24.2 \%(6.8-55.6)$ & $\begin{array}{l}\text { (Huxley and others } \\
\text { 2004) }\end{array}$ & $\begin{array}{l}15 \text { organic herds based in } \\
\text { the South West England. }\end{array}$ \\
\hline $25 \%(6.8-74.2)$ & (Huxley 2005) & $\begin{array}{l}28 \text { organic herds based in } \\
\text { the South West England. }\end{array}$ \\
\hline $\begin{array}{c}15 \% \text { (grazing) } \\
39 \% \text { (zero-grazed) }\end{array}$ & $\begin{array}{l}\text { (Haskell and others } \\
\text { 2006) }\end{array}$ & $\begin{array}{c}37 \text { herds assessed in a study } \\
\text { of zero-grazing. }\end{array}$ \\
\hline $36.8 \%(0-79.2)$ & $\begin{array}{c}\text { (Barker and others } \\
\text { 2010) }\end{array}$ & $\begin{array}{l}227 \text { herds from the } \\
\text { Midlands, Wales and South } \\
\text { of England (winter). }\end{array}$ \\
\hline
\end{tabular}

Estimates increase over time and the ranges are large i.e. some farms have very few lame cows where as on others the proportion of lame cows is very high.

\section{DEFINITION}

Prevalence is the proportion of cows that are lame in the total population at risk at a particular point in time. It is a fraction between 0 and 1 or more commonly expressed as a percentage. Mobility scoring of herds can be used to provide this estimate.

\section{$\frac{\text { Number of lame cows }}{\text { Total number of cows }}=$ prevalence}


Box 4. Changes in the UK dairy industry and the demands on milking cows ${ }^{1}$

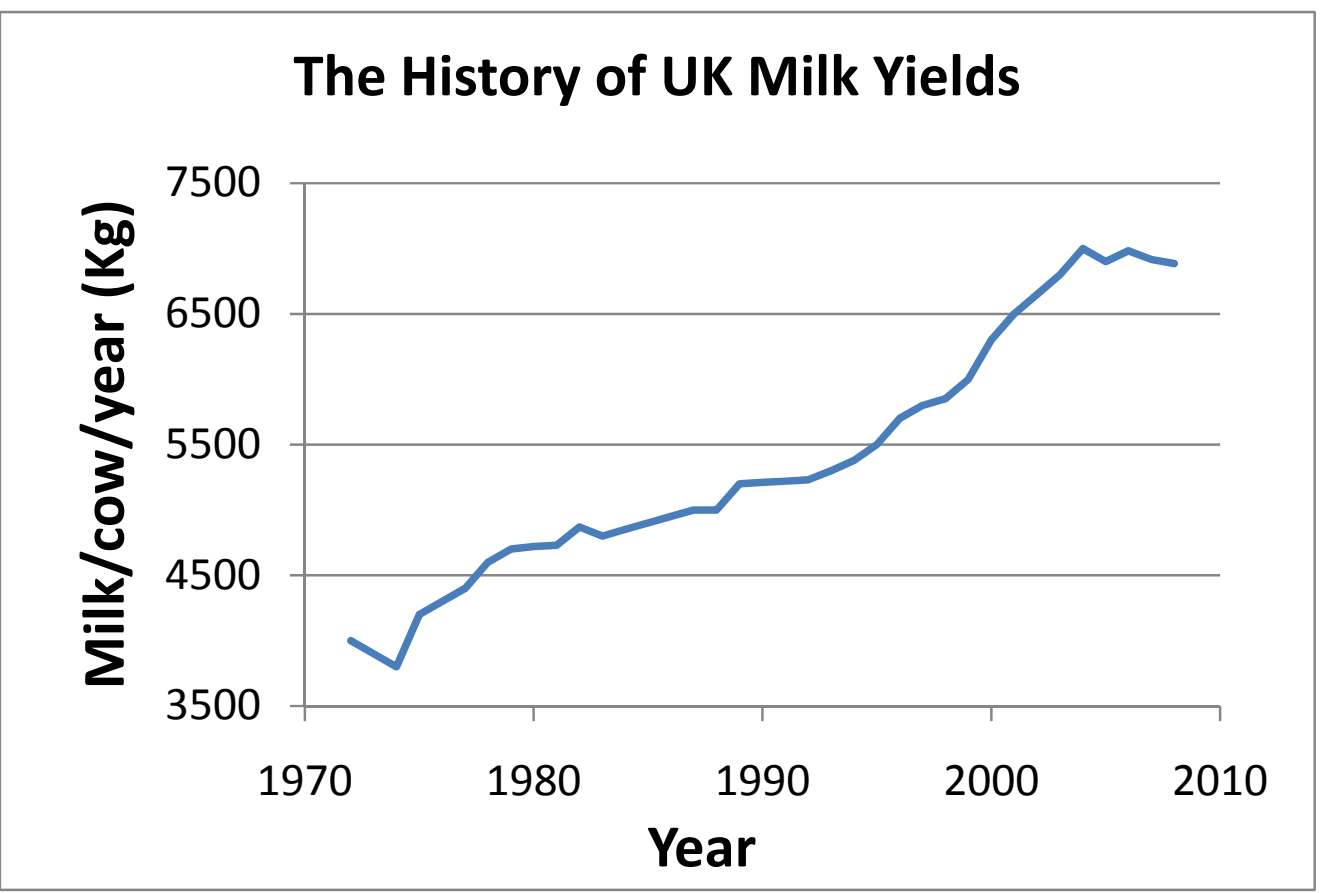

- The UK dairy herd has decreased by an estimated 552,000 head (22\%) over a 10 year period to 2008 with around 1.9 million cows kept on 17,060 holdings. The number of dairy farms in England and Wales, Scotland and Northern Ireland has decreased by $46 \%, 31 \%$ and $32 \%$ respectively over the same period.

- The human population in the UK stood at an estimated 61 million in 2007 and is growing; demand per capita per annum for milk products is stable. With minimal raw milk imports (currently $0.2 \%$ of the 13.2 billion litre UK milk market), increased milk production per cow is required to meet this demand (see graph above for UK trend). Average annual milk yield per cow in 2008 was 6885 litres

\footnotetext{
${ }^{1}$ Although curtailed in the EU by the quota system, milk production in the UK has been below this threshold since 2001. At present the cost of quota at less than $0.5 \mathrm{ppl}$ is not a limiting factor to efficient dairy farming.
} 
having peaked at 6990 litres in 2005. Overall falling cow numbers have contributed to UK milk production dropping by 857 million litres $(6.4 \%)$ over a decade to an all time low in 2008 of 12.9 billion litres.

- A UK dairy cow, giving $28 \mathrm{~L}$ of milk per day is performing at 3 times maintenance requirements for energy; this can reach 5 times maintenance requirements at $50 \mathrm{~L}$ per day.

- In the future, further efficiency gains will be required in order to limit environment impacts e.g. slurry production and green house gas emissions. 
Box 5: Mobility scoring requirements taken from a current UK milk buyers contract Mobility Scoring

- Members are required to score their herd every two months and record their details.

- Members will be required to produce an improvement plan based on their data as part of their veterinary health plan.

- Members must fund and arrange for an independent suitably qualified person to visit their farm and score their herd on an annual basis.

- Members are strongly advised to use their recording agency to capture herd mobility information. 


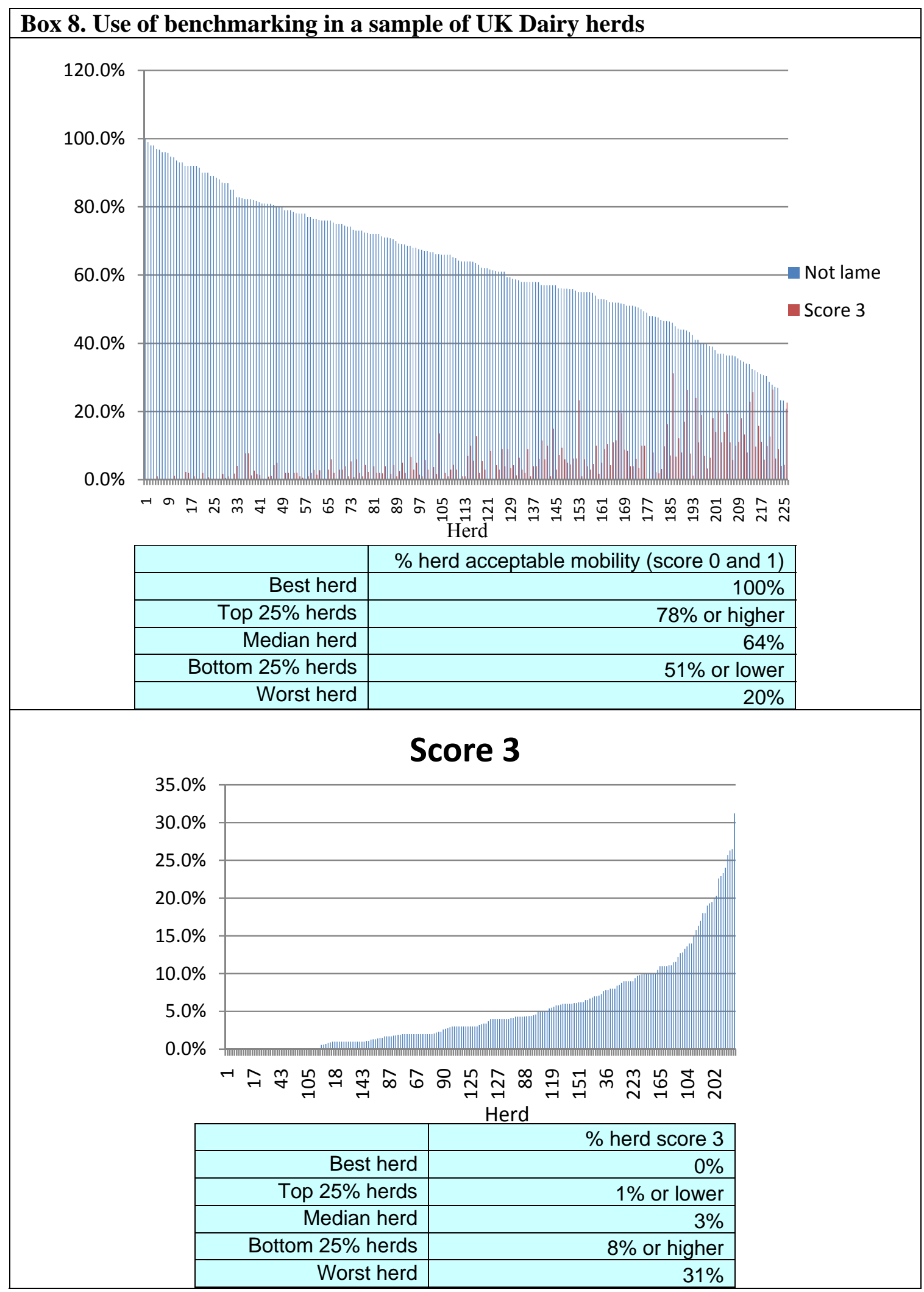


Box 9: Dynamic analysis of mobility scores

The following method is adapted from somatic cell count analysis and is recommended for analysis of serial mobility score data (Archer and others 2009).

1) Recode mobility scores.

\begin{tabular}{|l|l|}
\hline Mobility Scores & $\begin{array}{l}\text { Values used for } \\
\text { dynamic analysis }\end{array}$ \\
\hline \hline and 1 (Not Lame) & 0 \\
\hline 2 and 3 (Lame) & 1 \\
\hline
\end{tabular}

2) Assign categories.

\begin{tabular}{|l|l|}
\hline $\begin{array}{l}\text { Change in } \\
\text { disease state }\end{array}$ & Category \\
\hline \hline 0 to 0 & Not Lame \\
\hline 0 to 1 & New Case \\
\hline 1 to 0 & Recovered Case \\
\hline 1 to 1 & Chronic \\
\hline
\end{tabular}

3) Monitor proportion in each category over time and observe trends
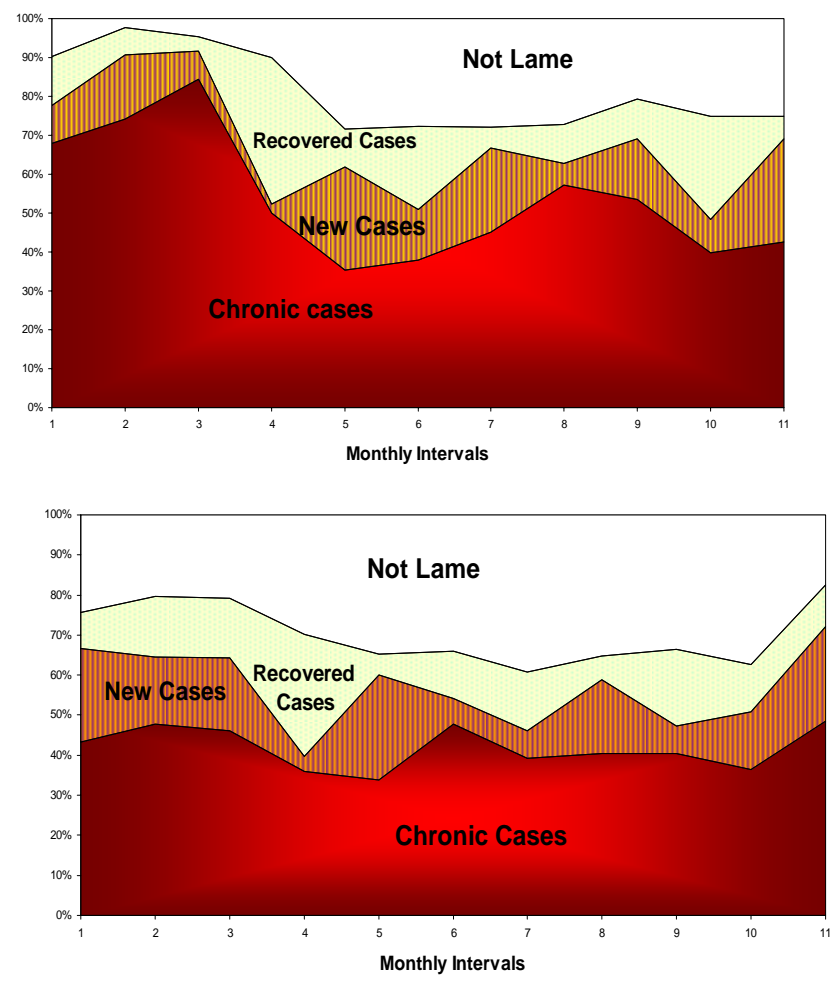

Herd A had a reduction in chronic cases possibly associated with installing a new parlour and reducing the time cows spent standing on concrete

Herd B has maintained a relatively steady state over a 12 month period

\section{4) Calculate Net Lameness Index (NLI) \\ $=\quad$ New cases Recovered cases}

5) Interpretation

$\mathrm{NLI}<1$. Lameness is improving. If NLI $>1$. Lameness is deteriorating.

\section{Limitations of dynamic analysis of mobility scores}

\section{PROBLEM}

Intervals between scoring sessions can be variable, and often long e.g. 6 months Only includes cows that were clearly identifiable on any two consecutive occasions.

\section{SOLUTION}

Encourage regular (i.e. at least monthly) mobility scoring Identification is most easily confirmed by checking with collar readings in the parlour, the person milking or if scoring is performed at 


\begin{tabular}{|l|l|}
\hline & $\begin{array}{l}\text { a time other than milking, having the herdsman } \\
\text { present to confirm identities }\end{array}$ \\
\hline $\begin{array}{l}\text { Does not include animals not present at milking } \\
\text { e.g. dry cows, young stock, recumbent cows. }\end{array}$ & $\begin{array}{l}\text { Use in conjunction with herd calving, drying } \\
\text { off and culling records. Check health records } \\
\text { and make enquiries at the visit. }\end{array}$ \\
\hline $\begin{array}{l}\text { Does not consider "acute" cases of lameness } \\
\text { that are treated between scorings. }\end{array}$ & $\begin{array}{l}\text { Consult farm treatment records if they exist or } \\
\text { make enquiries at the visit. }\end{array}$ \\
\hline
\end{tabular}


Box 10: Guidelines for consistent mobility scoring in practice

- Limit to a single observer for an individual farm.

- Observe cows walking on a flat, straight, non-slip, concrete surface in accordance with their normal routine.

- Ensure cows are not pressured so they pass at a gentle walk.

- Try to avoid using areas where there can be interruption to cow flow such as water troughs en route to a feed fence.

- Ensure accurate identification by scoring animals with the herdsman. With assistance, push all cows to one section of a shed and allow them to walk back past you. Alternatively, score at milking time so that freeze brands can be noted down while cows are milked and their mobility observed as they exit the parlour.

- Avoid scoring at the same time as other procedures likely to interfere with calm, uninterrupted walking e.g. TB testing, vaccination or foot bathing.

- Use a Dictaphone for recording data when cow flow is rapid.

- Consider training a paraprofessional for this task.

Note to editor: The mobility scoring photo would complement box 10.

Box 11: Estimated level of pain associated with two causes of lameness on a 10 point pain scale

\begin{tabular}{|llcc|}
\hline & & Median & Mode $^{\#}$ \\
\hline \multirow{3}{*}{ Digital Dermatitis } & UK Vets $\left(615^{*}\right)$ & 6 & 5 \\
& UK Farmers (939) & 5 & 5 \\
& European Vets & 6 & 5 \\
& $(2659)$ & & \\
& & \\
\hline
\end{tabular}


Box 12: The impact of clinical lameness on the milk yield of dairy cows

Studies on UK farms have demonstrated that cases of clinical lameness were associated with a decreased milk yield from up to 4 months before diagnosis until 5 months after resulting in a mean reduction of $357 \mathrm{Kg}(95 \% \mathrm{CI} 163$ to $552 \mathrm{Kg})$ per 305 day lactation. Sole ulcers and white line lesions were associated with a reduction in milk yield of 570 $\mathrm{Kg}$, and $330 \mathrm{Kg}$ respectively. A case of digital dermatitis was not associated with a decrease in milk yield (Amory and others 2008; Green and others 2002). 
Box 13: The impact of monthly mobility score on the milk yield of dairy cows (Archer and others 2010)

Estimated reduction in $\mathbf{3 0 5}$ day milk yield (Kg) for lame (score 2) and severely lame (score 3) cows, prompt effective treatment is assumed such that animals are not lame when reassessed after one month

\begin{tabular}{cccc}
\multicolumn{2}{c}{ DairyCo mobility score } & 2 (lame) & 3 (severely lame) \\
\hline Month of & 1 & 175 & 350 \\
lactation when & 2 & 150 & 250 \\
lameness case & 3 & 100 & 200 \\
occurs & 4 & 50 & 100
\end{tabular}

Estimated reduction in 305 day milk yield $(\mathrm{Kg})$ associated with chronic lameness for lame (score 2) and severely lame (score 3) cows

\begin{tabular}{rccc} 
DairyCo mobility score & 2 (lame) & 3 (severely lame) \\
\hline Number of & 1 & 175 & 350 \\
months into & 2 & 325 & 625 \\
lactation that & 3 & 425 & 800 \\
lameness & 4 & 475 & 900 \\
continues & 5 & 500 & 1000
\end{tabular}

Figures are given to the nearest $25 \mathrm{~kg}$ to aid translation into a clinical context. A full description of the data and results is available in the reference. 
Box 14: Components of the economic cost of individual lameness cases (Willshire and Bell 2009).

\begin{tabular}{|c|c|}
\hline $\begin{array}{l}\text { Direct costs - these are the costs that can } \\
\text { be attributed to each case of lameness } \\
\text { that may be specific to the farm and } \\
\text { individual case }\end{array}$ & $\begin{array}{l}\text { Indirect Costs - these are operational } \\
\text { costs that are not easily attributable to a } \\
\text { single case of lameness but are more } \\
\text { easily imputed by generalisations at herd } \\
\text { level }\end{array}$ \\
\hline $\begin{array}{l}\text { Treatment costs } \\
\text { - Time } \\
\text { - Opportunity cost }{ }^{2} \\
\text { - Veterinary and medicinal costs } \\
\text { - Discarded milk } \\
\text { - Reduced milk yield at time of } \\
\text { treatment }\end{array}$ & $\begin{array}{l}\text { - Increased calving to conception } \\
\text { interval } \\
\text { - Increased risk of culling. } \\
\text { - Increased risk of further lameness } \\
\text { - Increased risk of secondary diseases } \\
\text { e.g. displaced abomasa } \\
\text { - Reduced milk yield through } \\
\text { subclinical, treatment and recovery } \\
\text { phases } \\
\text { Depreciation on foot trimming } \\
\text { equipment. }\end{array}$ \\
\hline
\end{tabular}

${ }^{2}$ Time is a valuable commodity and always has an "opportunity cost" as alternative uses are foregone, for example time spent dealing with a lame cow may make less time available for preventative foot trimming. 
Box 15: Applied economics of lameness (Willshire and Bell 2009).

1) Assessing the value of "lost milk"

The potential loss in gross margin alone from a milk yield reduction of $357 \mathrm{~kg}$ per case of lameness would be worth $£ 68$ based on a margin over purchased feed of 19 ppl for year round calving herds with average annual milk yields of 6885 litres. If the same calculation is performed at herd level using typical incidence rates, lost milk revenue is an estimated $£ 1573$ for a 112 cow 'UK average' herd with 20.7 lameness cases per 100 cows per year (£23 per cow).

2) For the typical UK herds at the time of writing, the cost of lameness for the typical dairy farm can be calculated using the most recent estimates of lesion incidence rates (Barker 2009) and published figures for performance losses.

\begin{tabular}{|c|c|}
\hline \multicolumn{2}{|l|}{ Herd Details } \\
\hline Milk Price (ppl) & 22.5 \\
\hline Number of cows & 112 \\
\hline Calving Index (days) & 410 \\
\hline Calving to Conception (days) & 130 \\
\hline Dry Period Length (days) & 60 \\
\hline Days in milk at drying off & 350 \\
\hline $\begin{array}{l}\text { Weight of average cow in herd (kg) } \\
\text { Value of average calf }\end{array}$ & $\begin{array}{r}650 \\
\mathbf{f} 120.12\end{array}$ \\
\hline Value/kg of cull cow liveweight & $\mathrm{f} 1.00$ \\
\hline Margin over purchased feed (MOPF) & fo.19 \\
\hline 305d Yield (L) & \\
\hline Average cow peak yield (L) & 34.425 \\
\hline Yield peaks at (days/p-p) & \\
\hline Yield decline of cows per day & $0.30 \%$ \\
\hline Average yield per cow per day (L) & 19.67143 \\
\hline \multicolumn{2}{|l|}{ Feed Details } \\
\hline Type of feeding system & \\
\hline $\begin{array}{l}\text { Concentrate feeding rage }(\mathrm{kg} / \mathrm{l}) \\
\text { Cost of concentrate/tonne }\end{array}$ & $\begin{array}{r}0.25 \\
f 180.00\end{array}$ \\
\hline $\begin{array}{l}\text { Cost of concentrate/tonne } \\
\text { Cost of feeding HIGH yielder per day }\end{array}$ & $\begin{aligned} f 180.00 \\
f 0.00\end{aligned}$ \\
\hline Cost of feeding LOW yielder per day & \\
\hline
\end{tabular}
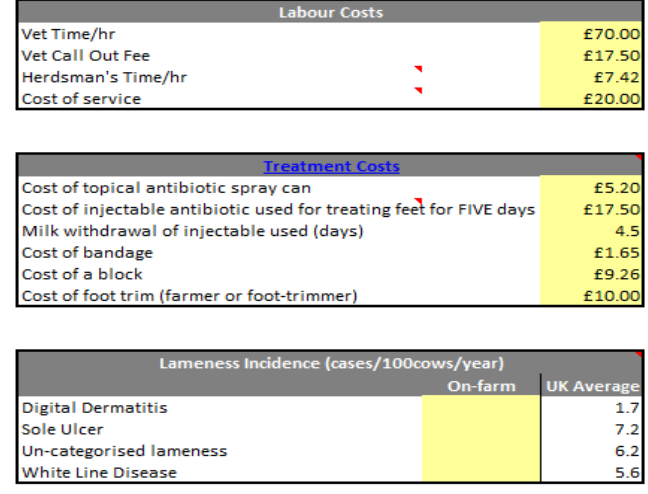

\begin{tabular}{|lrrr|}
\hline \multicolumn{4}{c|}{ Cost of Culling } \\
& Unit & \multicolumn{3}{c|}{ Cost/Unit } & Total \\
\hline Return from sale & 650 & $\mathrm{f1.03}$ & $\mathrm{f} 669.50$ \\
Cost of rearing replacement heifer & 1 & $\mathrm{f} 712.00$ & $\mathrm{f} 712.00$ \\
Lower milk vield from heifer & 1377 & $\mathrm{f} 0.19$ & $\mathrm{f} 261.63$ \\
Value of smaller calf from heifer & & & $\mathrm{f} 8.00$ \\
Total cost of culling & & & $\mathrm{f312.13}$ \\
\hline
\end{tabular}

${ }^{3}$ To increase credibility, margins should be used rather than the absolute milk price as feed and other inputs are saved when "lost milk" has not actually been produced. 


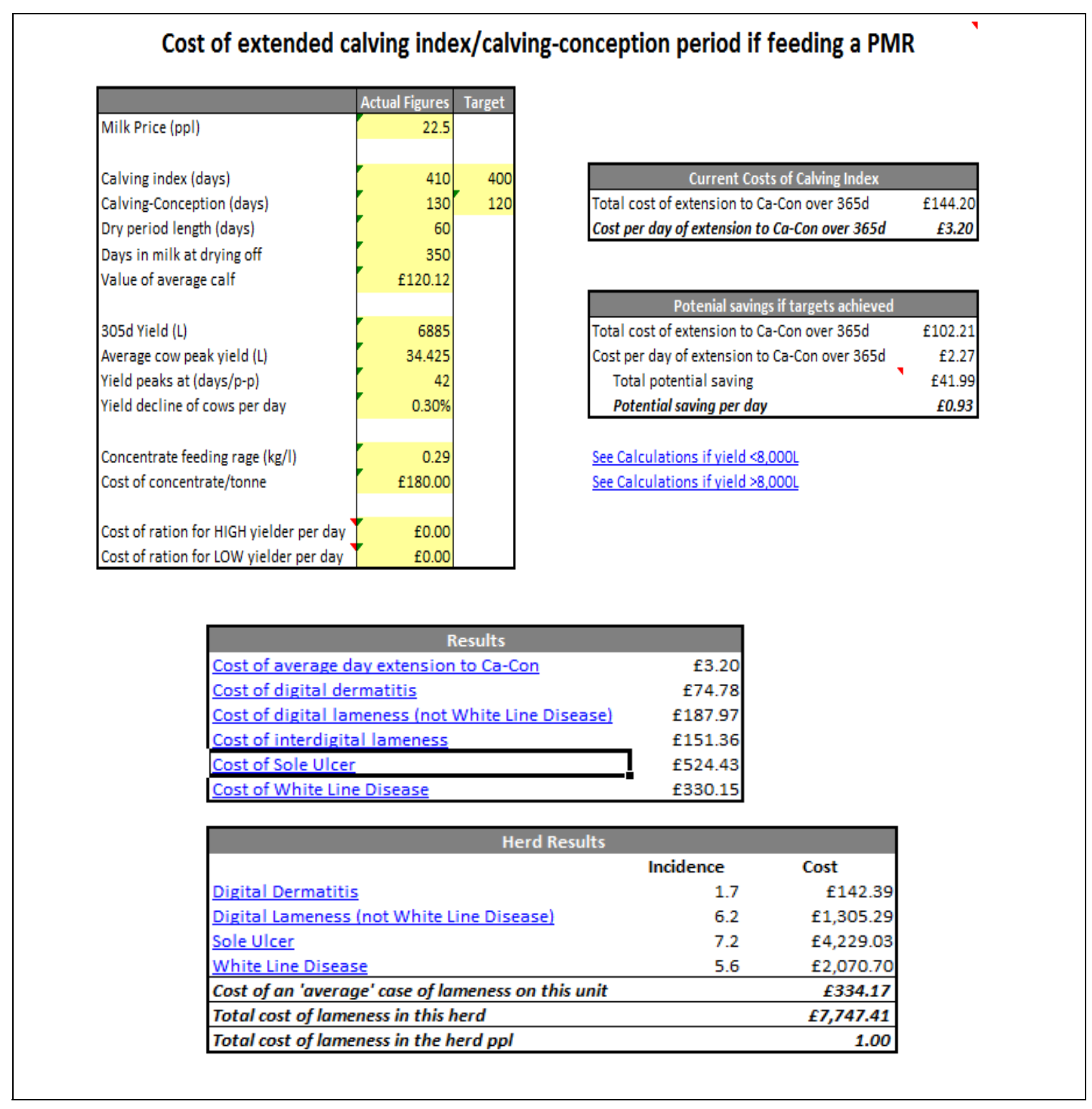




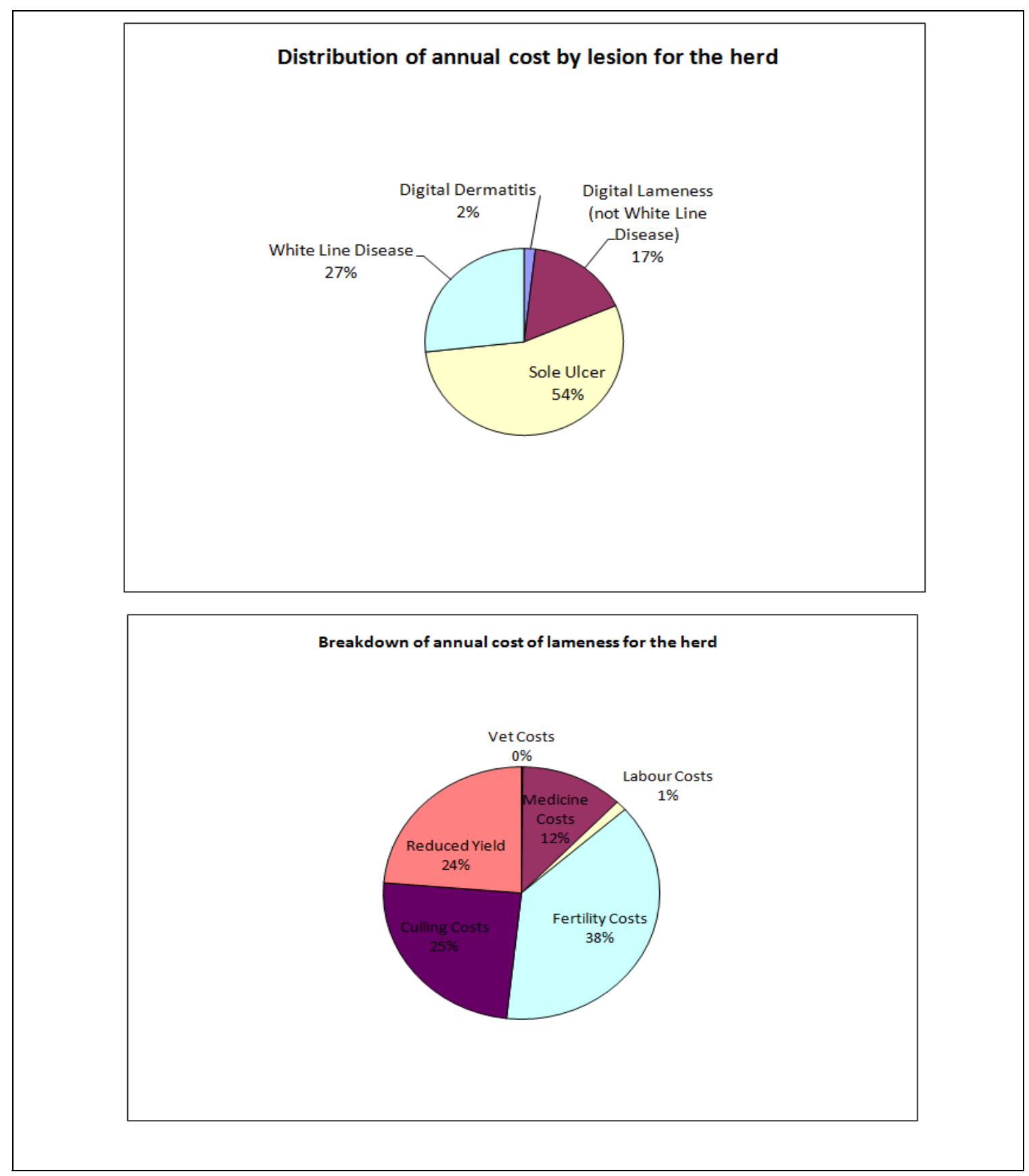


Box 16: Examples where further research into lameness control is needed

\section{Foot trimming}

Foot trimming is commonly recommended as an important lameness control measure. When done according to Dutch 5 step principles, foot trimming corrects claw shape to counteract the excessive growth of horn that occurs as a response to excessive wear on exposure to concrete flooring. Foot trimming is a skilled procedure which requires high levels of training and auditing of all those that undertake it; over-trimming is common practice.

Recent work has found that farms that employ a foot trimmer have higher lameness prevalence than those where the farm staff undertake all foot trimming. This could be for a variety of reasons: herds with most lameness have to recruit foot trimmers; that lameness becomes the delegated responsibility of the foot trimmer with farm staff become de-skilled and less interested; the time to treatment may be longer where lame cows are left until a foot trimmer visits leading to poorer outcomes following treatment; or the technique used by foot trimmers may be worse. As many foot trimmers are not members of the National Association of Foot trimmers and operate without any formal training or qualification, the latter may be important. The routine use of grinders has been challenged although there is no evidence to suggest the use of the grinder prevents correct claw trimming method being followed safely.

Within the cattle welfare codes it states "If they [sic stock-keepers] are expected to perform specific tasks on-farm, such as foot trimming, then appropriate training should be given. Otherwise, a veterinary surgeon or, for certain tasks, a competent and trained contractor will be required."

\section{Foot bathing}

Foot bathing is considered effective in the management of digital dermatitis although controlled clinical trials would only support the use of antibiotics, formalin, copper sulphate and peracetic acid. No products are currently licensed for foot bathing. This is disturbing as a range of unlicensed chemicals are used in an uncontrolled manner with potential for adverse public health and environmental consequences. Standard withdrawal periods apply to soluble POM-V antibiotics that are prescribed by veterinary surgeons for use off label in footbaths.

Occupational exposure to formalin is a risk factor for nasopharyngeal cancer in humans and its use without good evidence leaves vets open to litigation cases.

In terms of practical application, the standard of foot bath hygiene is probably more important than the product chosen since all are inactivated in the presence of organic 
matter. Feet should therefore be cleaned before cows walk through the bath, preferably in a separate prewash bath containing straw and water. Footbaths quickly become contaminated during use and could then represent more of a risk factor than a control measure if remedial action is not taken.

Box 17: Cattle foot lesion recognition and international nomenclature. Following the 15 th International Symposium \& the 7th Conference on lameness in ruminants, international consensus was reached on standardising foot lesion nomenclature. Lesions that could be grossly recognised were adopted, avoiding debate over diseases involving uncertain pathogenesis such as coriosis (formerly laminitis). The following terms should be used whenever possible

\begin{tabular}{|c|c|c|}
\hline Foot lesion & Description of lesion & Typical appearance \\
\hline $\begin{array}{l}\text { White line lesion also } \\
\text { known as (aka) White } \\
\text { line separation, White } \\
\text { line disease }\end{array}$ & $\begin{array}{l}\text { Diseased horn affecting } \\
\text { the junction between the } \\
\text { sole and wall, including } \\
\text { bruising (haemorrhage), } \\
\text { separation (fissuring), } \\
\text { abscessation and } \\
\text { ulceration. }\end{array}$ & \\
\hline $\begin{array}{l}\text { Sole ulcer aka } \\
\text { Pododermatitis } \\
\text { circumscripta, } \\
\text { Rusterholz disease }\end{array}$ & $\begin{array}{l}\text { Exposed corium at the } \\
\text { classic site } \\
\text { corresponding to the } \\
\text { flexor process of the } \\
\text { pedal bone }\end{array}$ & \\
\hline Heel ulcer & $\begin{array}{l}\text { Exposed corium found in } \\
\text { the midline of the claw } \\
\text { at the junction between } \\
\text { the sole and heel. } \\
\text { Usually affects medial } \\
\text { hind claws. }\end{array}$ & \\
\hline
\end{tabular}




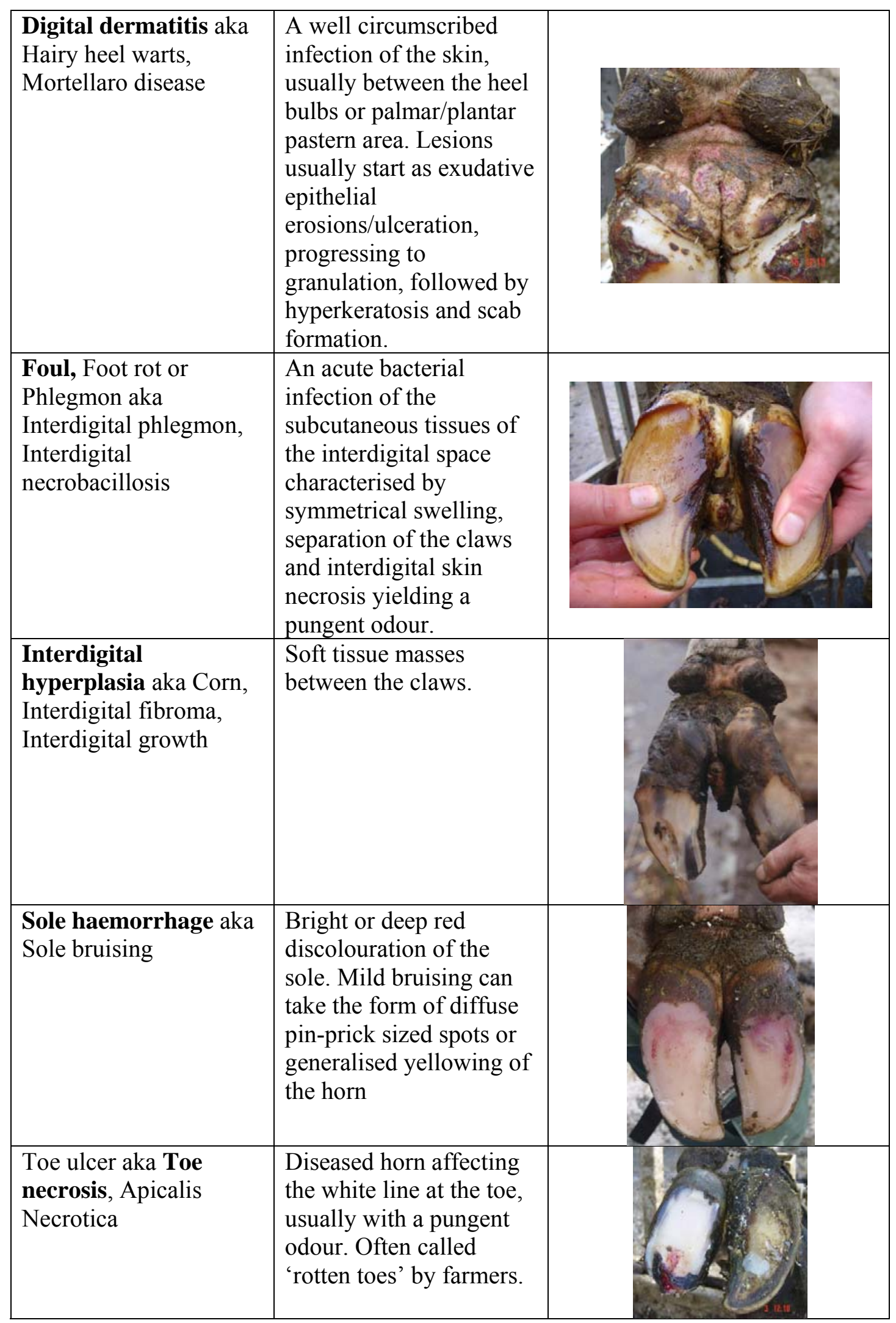




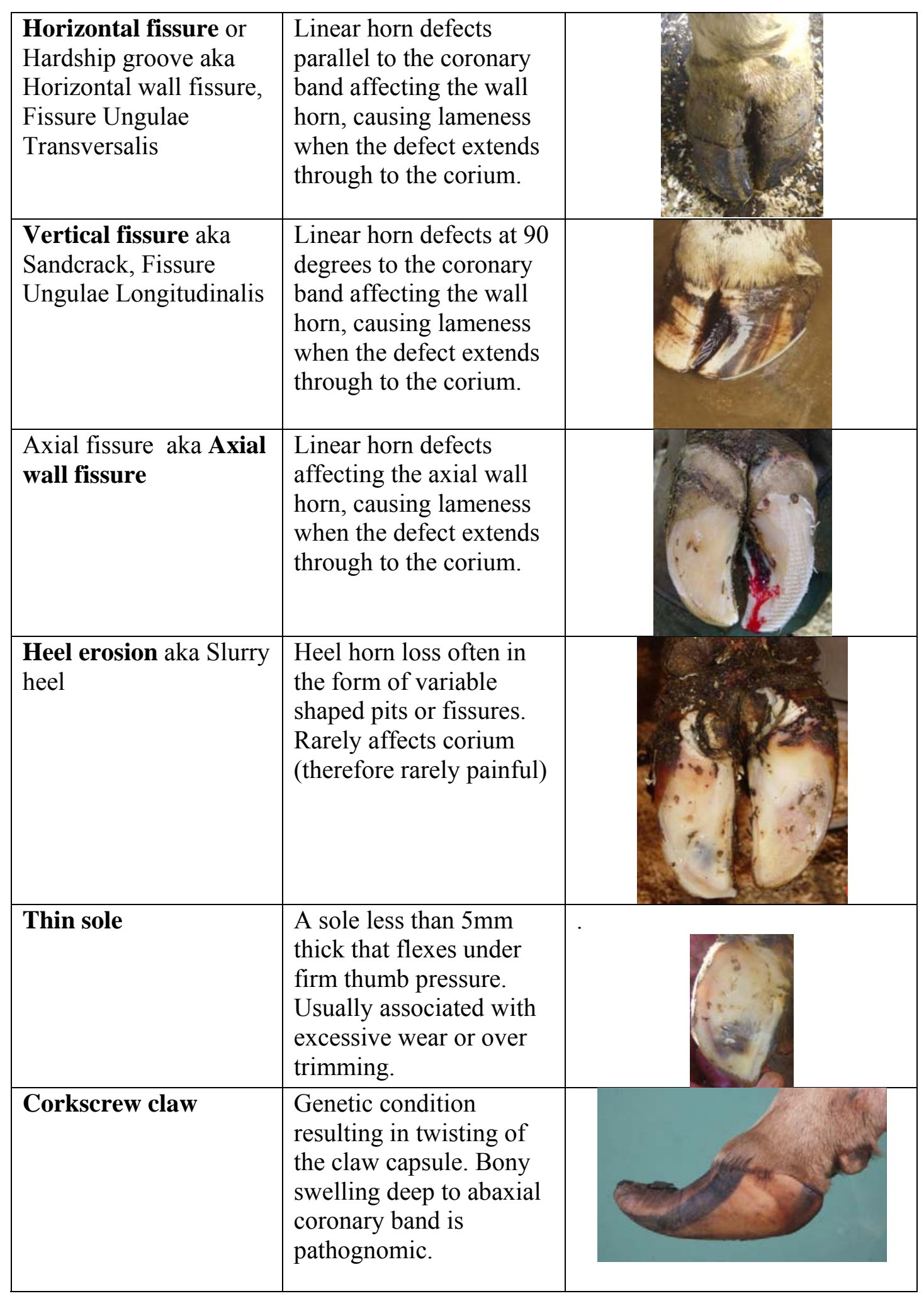




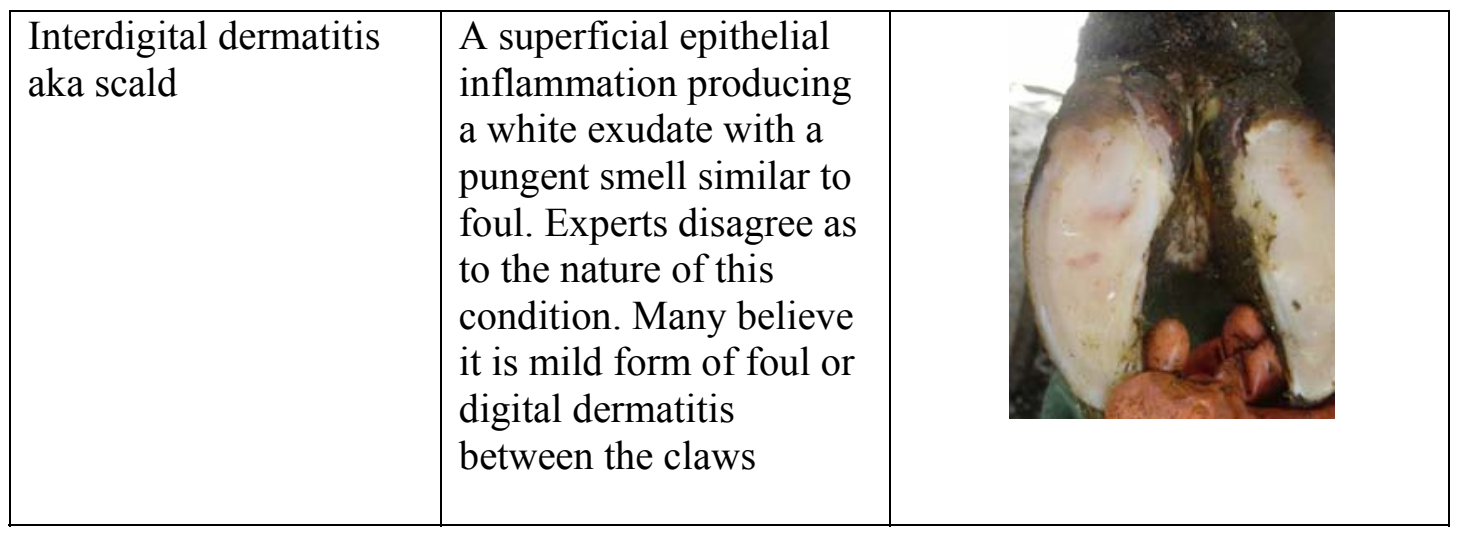

\section{$\underline{\text { References }}$}

AMORY, J.R., BARKER, Z.E., WRIGHT, J.L., MASON, S.A., BLOWEY, R.W. \& GREEN, L.E. (2008) Associations between sole ulcer, white line disease and digital dermatitis and the milk yield of 1824 dairy cows on 30 dairy cow farms in England and Wales from February 2003-November 2004. Preventive Veterinary Medicine 83, 381-391 ARCHER, S. C., GREEN, M. J. \& HUXLEY, J. N. (2010) The Association between Milk Yield and Serial Locomotion Score Assessments in UK Dairy Cows. Journal of

\section{Dairy Science Accepted for publication}

ARCHER, S. C., GREEN, M. J. \& HUXLEY, J. N. (2009) The Dynamics of Dairy Herd Mobility. In Cattle Lameness Conference 2009. Sutton Bonington, Leicestershire, UK., University of Bristol, The Dairy Group and University of Nottingham. pp 49-50 BARKER, Z. E., LEACH, K. A. WHAY, H. R., BELL, N. J. \& MAIN, D. C. J. (2010) Assessment of lameness prevalence and associated risk factors in dairy herds in England and Wales. Journal of Dairy Science 93, 932-941

BARKER, Z. E., AMORY, J. R., WRIGHT, J. L., MASON, S. A., BLOWEY, R. W. \& GREEN, L. E. (2009) Risk factors for increased rates of sole ulcers, white line disease, 
and digital dermatitis in dairy cattle from twenty-seven farms in England and Wales. Journal of Dairy Science 92, 1971-1978

CARTER, S., EVANS, N., TIMORFTE, D., BROWN, J., BLOWEY, R., MURRAY, R., BIRTLES, R. \& HART, T. (2009) Dermatitis - microbial aetiopathogenesis approaches providing opportunities for treatment. In Proceedings of the Cattle Lameness Conference (2009). Sutton Bonington, Leicestershire, UK. pp 9-18

CLARKSON, M. J., FAULL, W. B., HUGHES, J. W., MANSON, F. J., MERRITT, J. B., MURRAY, R. D., SUTHERST, J. E., WARD, W. R., DOWNHAM, D. Y.\& RUSSELL, W. B. (1996) Incidence and prevalence of lameness in dairy cattle. Veterinary Record 138, 563-567 COLLICK, D. W., WARD, W. R. \& DOBSON, H. (1989) Associations between types of lameness and fertility. Veterinary Record 125, 103-106 EDDY, R. G. \& SCOTT, C. P. (1980) Some observations on the incidence of lameness in dairy cattle in Somerset. Veterinary Record 106, 140-144

ESSELMONT, R. J. \& KOSSAIBATI, M. A. (1996) Incidence of production disease and other health problems in a group of dairy herds in England. Veterinary Record 139, $486-490$

GREEN, L. E., HEDGES, V. J., SCHUKKEN, Y. H., BLOWEY, R. W. \& PACKINGTON, A. J. (2002) The Impact of Clinical Lameness on the Milk Yield of Dairy Cows. Journal of Dairy Science 85, 2250-2256

HASKELL, M. J., RENNIE, L. J., BOWELL, V. A., BELL, M. J. \& LAWRENCE, A. B. (2006) Housing system, milk production, and zero-grazing effects on lameness and leg injury in dairy cows. Journal of Dairy Science 89, 4259-4266 
HEDGES, J., BLOWEY, R. W., PACKINGTON, A. J., O'CALLAGHAN, C. J. \& GREEN, L. E. (2001) A Longitudinal Field Trial of the Effect of Biotin on Lameness in Dairy Cows. Journal of Dairy Science 84, 1969-1975

HUXLEY, J. N. (2008) "Are Lameness and Infertilty in Dairy Cows Linked?" Cattle Practice 17, 13-15

HUXLEY J.N., DALMAU A., VAN DIJK P., GIDEKULL M., GUATTEO R., HELLEBREKERS L.J., HOLOPHERNE D., DE KRUIF A., MANTECA X., MÜLLER K.E., RANHEIM B., ROLLIN F., SVENDSEN O., TOUATI K., DE VLIEGHER S., WEBER C.N. \& Whay H.R. (2008) Current attitudes of European veterinary practitioners toward pain and the use of analgesics in cattle. Proceedings of 1st Boehringer Ingelheim Expert forum on farm animal well-being, Cardona, Spain, pp33 42.

HUXLEY, J.N. \& WHAY, H.R. Whay (2007) “Attitudes of UK Veterinary Surgeons and Cattle Farmers to Pain and the Use of Analgesics in Cattle" Cattle Practice 15, 189-193 HUXLEY, J.N. \& WHAY, H.R. (2006) “Current attitudes of cattle practitioners toward pain and the use of analgesics in cattle" Veterinary Record, 159 (20): 662-668 HUXLEY, J. N. (2005) An investigation into the effects of herd health planning and health and welfare benchmarking on cattle health and welfare on organic dairy farms in South West England RCVS Diploma thesis. Available from RCVS library London, UK HUXLEY, J. N., BURKE, J., RODERICK, S., MAIN, D. C. J. \& WHAY, H. R. (2004) Animal welfare assessment benchmarking as a tool for health and welfare planning in organic dairy herds. Veterinary Record 155, 237-239 
KELLY, J. M. \& WHITAKER, D. A. (2001) Multidisciplinary approach to dairy herd health and productivity management. . British Society of Animal Science Occasional Publication 26, 209-222

PRENTICE, D. E. \& NEAL, P. A. (1972) Some observations on the incidence of lameness in dairy cattle in West Cheshire. Veterinary Record 91, 1-7

RUSSELL, A. M., ROWLANDS, G. J., SHAW, S. R. \& WEAVER, A. D. (1982) Survey of lameness in British dairy cattle. Veterinary Record 111, 155-160 WHAY, H. R., MAIN, D. C. J., GREEN, L. E. \& WEBSTER, A. J. F. (2002) Farmer perceptions of lameness prevalence. In Proceedings of the 12th International Symposium on Lameness in Ruminants. Orlando, Florida, USA. pp 355-358 WHAY, H. R., MAIN, D. C. J., WEBSTER, A. J. F. \& GREEN, L. E. (2003) Assessment of the welfare of dairy cattle using animal-based measurements: direct observations and investigation of farm records. Veterinary Record 153, 197-202 WHITAKER, D. A., KELLY, J. M. \& SMITH, E. J. (1983) Incidence of lameness in dairy cows. Veterinary Record 113, 60-62

WHITAKER, D. A., KELLY, J. M. \& SMITH, S. (2000) Disposal and disease rates in 340 British dairy herds. Veterinary Record 146, 363-367

WHITAKER, D. A., MACRAE, A. I. \& BURROUGH, E. (2004) Disposal and disease rates in British dairy herds between April 1998 and March 2002. Veterinary Record 155, $43-47$

WILLSHIRE, J. A. \& BELL, N. J. (2009) An Economic Review of Cattle Lameness. Cattle Practice 17 136-141 